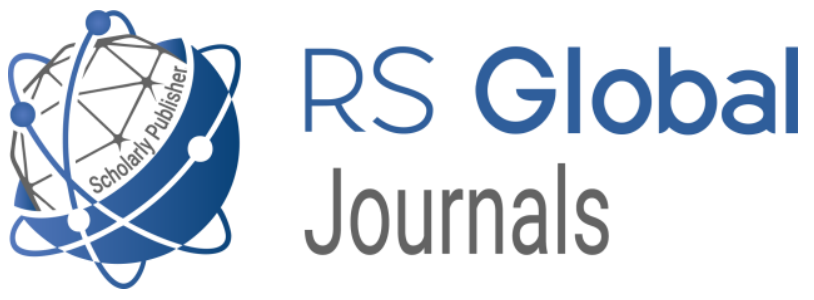

Scholarly Publisher

RS Global Sp. z O.O.

ISNI: 0000000484952390

Dolna 17, Warsaw, Poland 00-773

Tel: +48226022703

Email: editorial_office@rsglobal.pl

JOURNAL International Journal of Innovative Technologies in Social Science

p-ISSN $2544-9338$

e-ISSN

2544-9435

PUBLISHER

RS Global Sp. z O.O., Poland

ARTICLE TITLE

INTERNATIONAL EXPERIENCE OF HUMAN CAPITAL DEVELOPMENT AT THE LEVEL OF THE TERRITORIAL COMMUNITY

$\operatorname{AUTHOR}(\mathbf{S})$

ARTICLE INFO

DOI

RECEIVED

ACCEPTED

PUBLISHED

LICENSE
Andriy Rybka

Andriy Rybka. (2021) International Experience of Human Capital Development at the Level of the Territorial Community. International Journal of Innovative Technologies in Social Science. 1(29). doi: 10.31435/rsglobal_ijitss/30032021/7484 https://doi.org/10.31435/rsglobal_ijitss/30032021/7484

18 January 2021

14 March 2021

19 March 2021

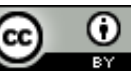

This work is licensed under a Creative Commons Attribution

4.0 International License.

(C) The author(s) 2021. This publication is an open access article. 


\title{
INTERNATIONAL EXPERIENCE OF HUMAN CAPITAL DEVELOPMENT AT THE LEVEL OF THE TERRITORIAL COMMUNITY
}

\author{
Andriy Rybka, Postgraduate student of the Department of Public Administration and Public Service \\ of the National Academy for Public Administration under the President of Ukraine, Ukraine \\ ORCID ID: https://orcid.org/0000-0001-8599-8268
}

DOI: https://doi.org/10.31435/rsglobal_ijitss/30032021/7484

\section{ARTICLE INFO \\ Received 18 January 2021 \\ Accepted 14 March 2021 \\ Published 19 March 2021 \\ KEYWORDS \\ Human capital, international experience, decentralization, territorial community, development.}

\begin{abstract}
Today, domestic scientists are carefully studying the process of development of the newly created united territorial communities, analyzing their main problems and challenges. However, it would be appropriate to combine such analysis with best international practices, which should help to increase the efficiency of the decentralization process in Ukraine and increase its effectiveness by taking into account both the advantages and disadvantages of international experience of community development in the frameworks of decentralization. Thus, the main tasks of the article are: to study the process of development of territorial communities of the European Union, to identify long-term areas for implementing the best international practice in Ukraine and to develop recommendations for human capital development at the local community level in the frameworks of decentralization.

Although the active process of decentralization began in Ukraine in 2014, our country is still in the process of reforming local self-government and decentralization of powers, which makes it especially important and relevant to study the experience of other countries. The issue of decentralization remains a key issue for the further formation of Ukraine's strategic development, however, the adoption of international models requires taking into account the specifics of the development of the state by itself. Since the current system of territorial community's operation in Ukraine is not perfect and still at the initial stage of its development, studying the experience of foreign countries will allow us to draw some conclusions about the prospects for further local communities development in Ukraine and to identify key areas of effective operation of territorial communities in Ukraine.
\end{abstract}

Citation: Andriy Rybka. (2021) International Experience of Human Capital Development at the Level of the Territorial Community. International Journal of Innovative Technologies in Social Science. 1(29). doi: 10.31435/rsglobal_ijitss/30032021/7484

Copyright: (C) 2021 Andriy Rybka. This is an open-access article distributed under the terms of the Creative Commons Attribution License (CC BY). The use, distribution or reproduction in other forums is permitted, provided the original author(s) or licensor are credited and that the original publication in this journal is cited, in accordance with accepted academic practice. No use, distribution or reproduction is permitted which does not comply with these terms.

Introduction. The transformation of the territorial structure of power, i.e. its decentralization, in particular establishment of territorial self-government, was considered as an important task in the process of restoring political and administrative systems in Central and Eastern Europe after 1989. Indeed, territorial government reforms took place after the collapse of communist regimes and the transformation of constitutional and central authorities in 1990.

Active integration of Ukraine into European structures leads to the establishment of an effective system of local self-government, increasing the role of community in resolving issues of local importance. However, despite the sufficient general elaboration of the issue and development of local communities in Ukraine, the urgent problems of determining the place of the territorial community in the system of local self-government, research of its functions and forms of activity, development of 
recommendations on formation of capable territorial communities with strong human capital, its involvement in local self-government, development of public institutions remain unexplored.

Materials and Methods. During preparation of the work the following general scientific methods were used: theoretical generalization, comparative analysis, analytical, and synthesis.

Results. Throughout the history of mankind, one of the most important tools for influencing individuals and society as a whole has been the social system and its main component - the human capital. Personal human capital, i.e. directly a person with his own abilities, skills, competence, personal qualities and properties is recognized as the highest value of the nation. Obviously, there is a need to preserve, accumulate and effectively use the human capital, which appears as a strategic resource for sustainable development of the economy and society as a whole. Education, health care and social security are considered to be the leading industries in the production of quality human capital.

Human capital of the territory (territorial community) should be considered as an investment in the social and economic development of human resources of the territory, conditions for improving the quality of life, foundation an information knowledge base, as well as the motivation system for various target groups. The experience of foreign development shows that optimization of territorial organization of power, strengthening of local self-government, formation of self-sufficient territorial communities is impossible without decentralization of power, which is the basis for ensuring a high standard of living and providing quality services at the local level. The world scientific community considers the economic development of communities as a process or strategy used to improve indicators of socio-economic development, increase welfare, ensure progress in the social and labor spheres, and so on. Development, from an economic point of view, concerns income, prices, savings, land tenure, the impact of social and class stratification, credit and financial system, education and health, organization and motivation of public authorities, public administration, leisure, selfimprovement and political climate. Community development is related to community progress. It is a process of developing and enhancing the community's ability to act collectively. The result of these actions is the improvement of indicators of socio-economic development of the community in terms of physical, social, political and economic spectrum [1]. Development is determined by the standard of living, which includes not only the personal property of the individual, but also the public goods he uses. The standard of living consists of several main components, which include: food, mainly agricultural and industrial production, housing, clothing, consumer goods, the system of protection of health, transport, communications, other social benefits, education, recreation and travel, etc. This is a multidimensional process that has a continuous character [2].

Today in Ukraine the reform of decentralization of power is underway, i.e. the transfer of powers and resources for their implementation from the state power as close as possible to the people, namely to the local self-governments. Considering that most of the developed countries of the world have a long tradition of reforms for decentralization of power, the foreign experience for Ukraine is extremely important and relevant. The democratic changes taking place in Ukraine are closely linked with the need to reform the system of public authorities and to develop the civil society institutions. The foreign experience of development shows that optimization of territorial organization of power, strengthening of local self-government, formation of self-sufficient territorial communities is impossible without decentralization of power, what is the basis for ensuring a high standards of living and providing quality services at the local level. Ukraine's state policy in the sphere of local self-government is based on the interests of residents of territorial communities and provides the decentralization of power - the transfer of large part of powers, resources and responsibilities from executive authorities to local selfgovernments. This policy is based on the provisions of the European Charter of Local Self-Government [3] and the best world standards of public relations in this area. At the same time, the newly formed local self-governments feel the lack of experience for effective use of available opportunities and resources in order to ensure sustainable socio-economic development of the community, what necessitates to study the leading world practice. Despite the numerous constitutional changes and additions which have been made in order to launch the decentralization processes in different countries, this is extremely important, where the main role is played by local self-government, growth of their powers and human resources, without which it is impossible to change and reorganize the system of public administration.

The new conditions provided by the implementation of decentralization reforms contribute to the creation of quality human capital, responsibility and active involvement of citizens at the local level in order to more effectively and efficiently manage their own communities and meet local needs. Despite the existence of different models of local self-government and the presence of national 
peculiarities in the distribution of powers between local and central authorities, there exist some common features which characterize decentralization processes in European countries.

Today there are five main characteristics of decentralization reform in European countries: democratization through the development of local and regional autonomy, the most effective solution to local problems, freedom through local and regional autonomy, cultural, linguistic and ethnic diversity, economic competition between local and regional level. Foreign experience shows the importance of decentralization for countries in the process of profound changes in the system of regulation of social relations. It should be noted that for countries in transition period, the decentralization appears as an effective way to develop the essential characteristics of society and has significant potential and prospects for local development.

The concept of "economic development of the community" is interpreted by world opinion mainly in two ways: the predominant focus exactly on economic development and inclusion of a wide range of components, among which, in addition to socio-economic development of the community, takes into account both the environment conditions and government activity [4].

In recent years, the theory and practical approaches to economic development of communities in the world's leading economies have undergone a kind of evolution. The initial application of the concept to ensure the development of backward regions and communities and the fight against poverty has become one of the fundamental approaches to sustainable development of society in Europe. First of all, it should be noted that the territorial community has many synonyms in European countries, which is primarily due to historical, linguistic, cultural and other factors of development process. The main synonyms of the territorial community are such concepts as "municipality", "commune", "gmina", etc. [5].

One of the first countries to carry out the administrative-territorial reform at the grassroots level in the post-war period was Germany, where, as in Ukraine, the territorial community is the primary subject of local self-government. According to the German Constitution of 1949, the community has the exclusive right to resolve local issues within the framework of national law [6]. Members of the territorial communities of Germany are characterized by a high degree of democracy in the expression of will. This is evidenced by such facts as: to support a local initiative in Germany, $1 \%$ of the community is enough, and in Ukraine is needed at least 10 thousand community members; convening a community meeting in Germany takes place at the request of $2.5 \%$ of the community, and in Ukraine - at least $10 \%$ of the community. One of the main features of the community in Europe is that they should be well populated and not too small in territorial terms. The state recognizes communities as "territorial corporations" and generally regulates the issue of their profits. Local self-government in Germany has two levels (districts and communities). In total, there are 439 districts in Germany, of which 323 districts and 116 cities under land subordination. The autonomy of German communities is based on the ability to exercise power in a certain territory, to organize the community, to adopt local law, including community statutes, to adopt local budgets and local taxes, to plan their own economic development, etc. [7].

There is a certain similarity between France and Ukraine in administrative-territorial structure at the local level. The similarity of countries lies in the size of their territory, number of population, structure of state power, as well as they have a similar territorial structure. Therefore, the experience of France in cooperation between regions and center is important for Ukraine, as France has achieved a lot in this sphere. The administrative system of the French Republic is characterized by a combination of administration by local state administrations and local self-governments, moreover together with introduction of decentralization idea in this country, more and more powers are gradually shifting from state to local government. The decentralization has also created in France three main levels of territorial units with a full set of powers for each of them. That is a commune, a department and a region. The term "commune" is used to mean a territorial community. A characteristic feature of French communities is their amount that is about 37000 . In France, more than 22 thousand communities consist less than 1,000 inhabitants [8]. In each of such a community there is a mayor and a municipal council, their powers do not depend on the amount of population. France's efforts to act towards decentralization have taken certain steps forward greater democracy in French society. Having simplified access to a significant number of necessary services, the powers of local councils have strongly increased. Local communities ask to provide them additional powers, so it can be assumed that France will face further decentralization in the future.

Another country bordering Ukraine in the west and whose experience is worth analyzing is Poland. The main administrative unit in Poland is the community. These local authorities exist both in rural areas, where they are called gminas, and in cities as well. In some cases, gminas and cities have formed joint units of local self-government. Communities are governed by councils elected by the local population. The 
number of council members depends on the population of the area, although any council can't have more than a hundred members. The executive body of the council is a board consisting of the mayor, the deputy mayor and no more than five others. In Poland, there are 380 counties and 2477 gminas, each of which unites 10-12 villages. Today, the commune's own powers include exactly what is normal for the powers of territorial lower-level authorities in a united Europe: water supply and sewerage; collection and disposal of solid waste; street cleaning and lighting; central heating; gas; maintenance and construction of local streets and roads; city public transport; housing and communal services; provision of educational services, including primary schools; culture; social security for the elderly, the disabled and the homeless, housing issues; physical planning, building permits. The simple nature of the territorial division of Poland, which is a certain guideline for Ukraine, contributed to the adoption of the law that the inhabitants of the commune is able to establish a self-governing community. The commune or gmina performs social tasks on its own behalf and under its own responsibility. The commune may create additional administrative units located on its territory: villages with a village headman, districts, settlements, a city. Additional units shall be created by the decision of the commune council after consultation with residents or on their initiative [9]. The finances of local self-governments in Poland consist of their own revenues, forming so-called independent budgets. They consist of revenues from taxes established on the basis of separate laws, revenues received by separate subdivisions of communes, revenues from budget enterprises, from the property of the commune, inheritance, records, donations, revenues from fines and penalties. It is generally believed that Polish administrative reform was successful. However, despite the positive results of decentralization in Poland, one of the points of criticism was the disregard for the difference between rural and urban counties, in particular, the different amount of resources which can be disposed of by these selfgoverning units. For most of Poland's underdeveloped regions, decentralization has meant a widening gap between the most successful Polish regions and the country in whole. Regions left without state assistance began to develop worse after the administrative reform. At the same time, it should be noted about the widespread use of new technologies in Poland in order to ensure the interaction between the government and community members. In particular, $90.5 \%$ of communes use the Internet to involve the population in solving local issues. This serves as a confirmation that in Poland members of territorial communities are quite actively involved in resolving issues of local importance and have a significant influence on local government bodies and officials.

What advice can Poland provide to Ukraine in terms of human capital formation at the level of the territorial community? As the experience of Poland shows, large communities are more effective, so it is worth using opportunities for growth, in addition, it is provided by Ukrainian law i.e. accession, unification, inter-municipal cooperation. Donors choose a larger community because it is more beneficial, more people can benefit and be involved. Therefore, joint projects of some gminas supported by programs of the European Union are actively developing in Poland. The European Commission wants to invest in real change and therefore is more interested in working with local self-government and less with politics. In Poland, it is well understood that schools are not premises, but the human capital, schools were transferred to the management of communes eight years after the beginning of decentralization, but in Ukraine it is better to do it simultaneously. In Poland, there exist some associations who receive licenses and undertake the education of children in those educational institutions where gminas are unable to maintain it. Given that the financing of the education system is based on the principle of "money follows the child", the commune transfers the established 5,200 zlotys per year for each student and the further search of funds is the responsibility of association. The education of one child costs from 7 to 13 thousand zlotys per year. As the part of medical reform, the insurance fund was established in Poland. Unlike education, the commune is not responsible for providing medical services. Neither hospital is funded from the local budget, merely through the insurance fund. All family doctors are entrepreneurs. The funds of the commune in this area are used only for the prevention purposes (for example, dentists in schools), group specialized examinations (medical examinations) and vaccinations. Migration of the population from the village to the city, from the city to the capital, from country to country is widespread, but migration creates competition among employers. Not only at the level of wages, but also in working conditions. If my competitor offers a higher salary than me, and I am unable to do so for economic reasons, then I have to find some other ways to attract an employee. Here it is necessary to determine the real needs of people and apply creativity.

The Republic of Latvia took a slightly different path, where the question regarding amalgamation of small and medium-sized municipalities in 1992 and 1993 took part, but the decision was never made for a number of reasons: frequent changes of governments, lack of political will, ignorance the opinion of local residents, the need for coercive amalgamation. After 
lengthy discussions, on October 21, 1998, the Seimas of Latvia adopted the Law "On Administrative and Territorial Reform" in a compromise version [10]. This was the first comprehensive legislative attempt to solve the problem of improving the administrative-territorial system. It was planned that the administrative-territorial reform of Latvia would be carried out in two stages: 1) under the initiative of local authorities by December 31, 2003 (voluntary association); 2) according to the project developed by the relevant state institution, from January 1, 2004 to November 30, 2004 (forced amalgamation of municipalities). The law defined the general criteria used to form a new local government body: ensuring long-term and balanced development of the territory; proper financial and tax base; the size of the territory; availability of infrastructure to perform the functions of local government; number, density of permanent population; economic, geographical and historical unity of local self-governments; availability of services provided by the municipality; taking into account the interests of neighboring municipalities. At the end of 2000 and the beginning of 2001, the Project of Administrative and Territorial Division of Local Self-Government was developed, which contained criteria for the formation of new territories and proposals for the establishment of 102 municipalities. The main criteria were: the population in the newly created administrative units should be more than 5,000 people; the presence of a developed center with a population of $2000-25,000$ people; orientation of the road system from separate parts to the administrative center; the distance between the center and the boundaries of the basic administrative-territorial unit does not exceed $30 \mathrm{~km}$. [10].

Each country has applied its own way of organizing the decentralization of power associated with its history, political and managerial culture, economy, social experience. Relevant differences make it impossible to develop and implement a common (universal) EU model. After analyzing the above mechanisms of formation of territorial communities, we can conclude that each of these ways is effective. However, there are some similarities in approaches for solving a number of problems. First of all, this applies to the increased administrative role of the regional level. Thus, the research data show that the territorial communities of European countries have a certain influence on the decisionmaking processes of local self-governments and able to make decisions on certain issues. Solving various problems of the respective territorial community, local communities manifest themselves in all spheres of local life: political, economic, social and cultural. The activity of members of territorial communities is most pronounced in addressing issues related to the human capital formation, i.e. improving living conditions, social protection, planning and organization of public services, security and crime control, services, education, health and environment protection and so on.

There are a number of theories of local economic development, including market theory, human capital theory, social capital theory, effective self-government theory, competition theory, but no scientific approach can offer a universal model of effective human capital formation at the territorial community level. In this context, it is the local self-government bodies that should take on the initiating role as public institutions that can ensure the effective use and capacity building of the community, increase the level of its socio-economic development. Their main task is that "regardless of the chosen approach to local economic development, the main measures should be aimed at increasing the number and variety of job offers for local residents [11]. That is, today the world practice of ensuring sustainable development of local areas and territorial communities has formed one of its key principles - the formation and strengthening of human capital.

Community capacity building focuses on enabling all members of the community, including the poorest, to develop professional skills and abilities, to improve the social issues of their lives, and to promote local development. Meaningful and effective capacity building of the community will promote and stimulate the development and capacity building of regions and the state as a whole. The need to build the capacity of local areas is also recognized by the United Nations Development Program (UNDP), which sees this process as creating an enabling environment with appropriate policies and legal frameworks, institutional development and community participation. It is noted that increasing the human capital of communities is a long-term process in which should participate all stakeholders. Thus, local governments should focus in detail, primarily on vacancies creation, studying existing labor offers inside the community, available human capital, the state of economic development of the community, the qualifications of workers who are in demand on the local labor market, available base of resources, etc. Such activities require a balanced approach, the formation of a clear methodology and effective implementation mechanisms in order to achieve the main goal - the sustainable socio-economic development of the united territorial community. 
In recent years, Ukraine has also made significant progress towards creating conditions and providing opportunities for socio-economic development of local territories. In particular, significant progress has been made in reforming the centralized system of public financing for the development of regions and settlements towards the decentralization of powers and resources with the formation of amalgamated territorial communities. In September 2019, the President of Ukraine signed a decree "On the Sustainable Development Goals of Ukraine until 2030." As the result of this work became a national system consisting of 86 tasks for national development. The goals of sustainable development for Ukraine until 2030 include priority areas of development: fair social development, sustainable economic growth and employment, effective governance, environmental balance and building sustainability. Global goals are to overcome poverty, provide quality education, health care, well-being and decent work [12]. They are universal and closely linked to key EU values. In accordance with the modern requirements of the European Union, the sustainable development of the state must be the main goal of regulating issues in all spheres of public life. When developing policies or actions in one area of public life, the possible effects of economic, environmental and social impacts (both positive and negative) on other areas of policy should be identified. The European Union works for the sustainable development of Europe, based on balanced economic growth, price stability, the social orientation of a market economy, vacancies creation, a high level of education, social progress, protection and improvement of the environment, and so on.

Despite the great progress in the formation and development of the territorial community, it should be noted the passivity of citizens of Ukraine, low level of participation of villagers, towns and cities in independent, self-responsible activities to address local issues. These circumstances require the development and implementation of measures aimed at involving members of local communities in local self-government, abandoning the traditional approach to considering local residents as customers of government, passive consumers of management services, the need to move to community development based on activity, initiative residents, using their potential to address issues of local importance and strengthening the human capital of the community. The following general principles of governance are important for achieving sustainable development: the responsibility of the state for sustainable development and nature preservation, public participation in decision-making processes at the local level.

One of the real problems that arise in the reorganization of territorial communities is the problem of ensuring the real capacity of the newly formed amalgamated communities of the relevant administrative-territorial unit. The key point here is the availability of appropriate human resources, financial support and infrastructure development.

Conclusions. The commonweal and sustainable development of any nation depends on the human capital, so a well-thought-out and consistent policy in the field of development and conservation of human resources is needed. The experience of European reforms is quite important for our state, but it should not use it mechanistically. In the context of globalization of the economy, various forms of participation in economic activities must fit into the framework of state and regional policy. According to the European experience the formation and development of human capital in territorial communities requires the implementation of a number of conditions, namely: creating an innovative educational environment in the united territorial community, involving members of the united territorial community to solve their own problems and promote their active participation in society, creating opportunities for professional development and rehabilitation. These conditions will have a positive impact on the process of preserving human capital in the newly formed territorial community.

The main direction of implementation of international experience in Ukraine is further amalgamation of territories with increasing the level of their financial capacity, improvement of organizational, legal and financial mechanisms for the implementation of this process. The study of best international practices indicates that the development of human capital in territorial communities in the context of decentralization should be based on the voluntary consolidation of territories into integrated communities under the control of the state in the frameworks of its functions.

Thus, today the problem of implementing Ukraine's strategic choice remains a rather difficult task not only against the background of the foreign policy and economic situation in the country, but also due to problems during the implementation of domestic reforms. Despite taking into account the experience of other countries on decentralization, this concept is still unclear to most Ukrainians, because the introduction of such a system abroad is due to historical experience, taking into account the specifics of the formation and development of a particular state. Therefore, given the world's positive experience in the development of territorial communities, we should not forget that borrowing a certain model does not guarantee success during its implementation in Ukraine. 


\section{REFERENCES}

1. Puziah, A., Yusof, F., Faizul, A. (2013). Local economic growth and community sustainability. Quality of Life in the Built and Natural Environment. Retrieved from https://pdf.sciencedirectassets.com/277811/1s2.0-S1877042813X00333/1-s2.0-S1877042813021125/main.pdf?X-Amz-Security

2. Bhatia, V.K., Rai, S.C. (2004). Evaluation of socio-economic development in small areas. New Delhi: Planning commission government of India. Evaluation of socio-economic development in small areas. New Delhi, India: Planning commission government of India

3. Council of Europe (1985). The European Charter of Local Self-Government. Retrieved from https://www.coe.int/en/web/conventions/full-list/-/conventions/treaty/122

4. Shaffer, R., Deller, S., Marcouiller, D. (2006). Rethinking community economic development. Economic development quarterly. Oxford, UK: Basil Blackwell

5. Bezuglyi, O. (2006). Svitovyi dosvid organizacyi staloho rozvytku teritoryalnoi hromady. [World experience of sustainable development of the territorial community]. Kharkiv, UA: Magistr

6. Bagan, M.P. (2002). Urydychna encyclopedia. Osnovnyi zakon Federativnoy Respubliky Nimechiny. [Basic Law of the Federal Republic of Germany. Legal encyclopedia]. Kyiv, UA

7. Riyaki, V.O. (2006). Osnovy konstituciinoho prava Federativnoy Respubliki Nimechina. Konstituciine pravo zarubignyh krain. [Fundamentals of constitutional law of the Federal Republic of Germany. Constitutional law of foreign countries]. Kyiv, UA: Urinkom Inter

8. Pustovoit, L. (2010). Systema dergavnoho upravlinnya Respubliki Francia: dosvid dlya Ukrainy. [The system of public administration of the Republic of France: experience for Ukraine]. Kyiv, UA: NADU

9. Alfiorov, S. (2013). Osoblyvosti ustrou funkcionuvannya teritorialnyh hromad krain-chleniv ES. [Features of the functioning of territorial communities of EU member states]. Kyiv, UA. http://nbuv.gov.ua/UJRN/pprbsu_2013_37_21

10. Matvienko, A. (2013). Obednannya teritorualnyh hromad: dosvid Finlyandii ta Latvii. [Association of territorial communities: the experience of Finland and Latvia]. Kyiv, UA: NAN Ukrainy

11. Giloth, R.P. (1998). Jobs and economic development strategies and practice. Michigan, USA: Sage Publications

12. The Law of Ukraine (2019). About the Sustainable Development Goals of Ukraine for the period up to 2030. Retrieved from https://www.president.gov.ua/documents/7222019-29825 